\title{
internal goods of teaching in philosophy for children: the role of the teacher and the nature of teaching in philosophy for children ${ }^{1}$
}

\author{
riku välitalo ${ }^{2}$ \\ oulu university - finland
}

\begin{abstract}
\end{abstract}
Philosophy for Children (PFC) promotes a pedagogy that builds on a collective process of truth-seeking and meaning-making. In contrast to seeing teachers as sources of knowledge, they are often described as facilitators in this communal process. PFC is part of the larger movement in education that has aimed to put the child at the center of the teaching and learning process. Yet, PFC, similar to other child-centered pedagogies, brings new challenges to understanding the role of the teacher. This article traces the questions concerning the pedagogy of PFC by incorporating Alasdair Macintyre's (1984) notion of practice and the scholarship of PFC. Macintyre's concept of practice offers the source for unveiling the internal goods of teaching in PFC. This article locates the internal goods in the teacher and in the work or performance of the teacher. Especially, a particular moral phenomenology and a biographical genre of a PFC teacher are articulated to flesh out the internal goods found in the teacher. The work of the teacher is characterized as entailing two components that shape its role. One is in composing a platform for collective progress grounded on epistemic criteria and another level of specifically educational judgements the teacher has to make individually, which together form the internal goods found in the performance. The nature of teaching and the role of the teacher in PFC provides a set of goods for the PFC teacher in his or her educational task.

keywords: internal goods; philosophy for children; alasdair macintyre; community of inquiry.

\section{bens internos do ensino na filosofia para crianças: o papel do professor e a natureza do ensino em filosofia para crianças}

resumo

A Filosofia para Crianças (FPC) promove uma pedagogia que se constrói sobre um processo coletivo de busca pela verdade e construção de significado. Ao invés de encarar os professores como a fonte do conhecimento, eles são mais frequentemente descritos como facilitadores neste processo comum. A FPC é parte de um movimento mais abrangente na educação, que tem por objetivo o de colocar a criança no centro do processo de ensino e de aprendizagem. Contudo, a FPC, similarmente a outras pedagogias centradas na criança, traz novos desafios para o entendimento do papel do professor. $O$ presente artigo mapeia as questões relativas à pedagogia da FPC incorporando a noção de pratica de Alasdair Macintyre's (1984) e a educação da FPC. O conceito de prática de Macintyre oferece a fonte para desvendar os bens internos do ensino na FPC. Este artigo situa os bens internos no professor e no seu trabalho ou performance. Especialmente, uma fenomenologia moral particular e o estilo biográfico de

\footnotetext{
${ }^{1}$ In preparing this paper I have been assisted by Olivier Michaud, and I would like to express my very great appreciation for his comments. Advice given by Hannu Juuso and Pauli Siljander has also been a great help during the process.

2 E-mail: riku.valitalo@gmail.com
} 
internal goods of teaching in philosophy for children: the role of the teacher and the nature of teaching in philosophy for children

um professor de FPC são articulados para expor os bens internos encontrados no professor. O trabalho do professor é caracterizado como implicando dois componenetes que formam o seu papel. Um deles compõe a plataforma para o progresso coletivo baseado em critérios epistêmicos e outro nivelamento dos julgamentos especificamente educacionais que o professor deve fazer individualmente, que juntos formam os bens internos encontrados na performance. A natureza do ensino e o papel do professor em FPC fornecem um conjunto de bens para o professor de FPC em suas tarefas educacionais.

palavras-chave: bens internos; filosofia para crianças; alasdair macintyre; comunidade de investigação.

\section{bienes internos de la enseñanza de la filosofía para niños y niñas: el papel del profesor y la profesora y la naturaleza de la enseñanza en filosofía para niños y niñas.}

resumen

La filosofía para niños y niñas $(\mathrm{FpN})$ promueve una pedagogía que se construye sobre un proceso colectivo de busca por la verdad y construcción del significado. En vez de encarar los profesores y profesoras como la fuente de conocimiento, ellos y ellas son descritos frecuentemente como facilitadores y facilitadoras del proceso común. FpN es parte de un movimiento más amplio en educación, que tiene por objetivo colocar al infante en el centro del proceso de enseñanza y aprendizaje. Con todo, FpN, similarmente a otras pedagogías centradas en los niños y niñas, trae desafíos nuevos para el entendimiento del papel del profesor y la profesora. El presente artículo mapea las cuestiones relativas a la pedagogía de FpN incorporando la noción de práctica de Alasdair Macintyre's (1984) y la educación de FpN. El concepto de práctica de Macintyre ofrece a fuente para desvelar los bienes internos de la enseñanza en $\mathrm{FpN}$. Este artículo sitúa los bienes internos en el profesor y la profesora y en su trabajo o performance. Especialmente, una fenomenología moral particular y el estilo biográfico de un profesor y una profesora de $\mathrm{FpN}$ son articulados para exponer los bienes internos encontrados en el profesor y la profesora. El trabajo del profesor y de la profesora implican dos componentes que caracterizan su papel. Uno de ellos compone la plataforma para el progreso colectivo basado en criterios epistémicos y otro el nivelamiento de los juicios especificamente educacionales que el profesor y la profesora deben hacer individualmente. Juntos forman los bienes internos encontrados en la performance. La naturaleza de la enseñanza y el papel del profesor y la profesora en $\mathrm{FpN}$ ofrecen un conjunto de bienes para el profesor y la profesora en sus tareas educacionales.

palabras clave: bienes internos; filosofía para niños y niñas; alasdair macintyre; comunidad de investigación. 
internal goods of teaching in philosophy for children: the role of the teacher and the nature of teaching in philosophy for children

Philosophy for Children (PFC) was established in the 1970s as an educational program that promotes a radical change in our understanding of growth, teaching, and the relationships that are formed in educational contexts. From the start, the primary mission was to emancipate the child by developing an educational practice that creates possibilities for his or her agentic action (LIPMAN; OSCANYAN; SHARP, 1980; MATTHEWS, 1984). The aim of this pedagogical approach was to transform the classroom into a reflective environment where young inquiring minds have a space for the mutual exploration of ideas.

By emphasizing collective reason in its pedagogy, PFC scholarship has promoted a radical change in the teacher's role, shifting it from being an authoritative figure to being more like a co-inquirer in the classroom (LIPMAN, 2003; GREGORY, 2004; HAYNES; MURRIS, 2011). In recent decades, we have witnessed increasing interest in student-centered pedagogies, which can be seen, for example, in the tendency to refer to teachers as facilitators not only in PFC, but also in other fields of education (see, for example, BIESTA, 2010; 2012).

Although this new shift has been a triumph for student-centered pedagogies like PFC, it has also caused worrying developments in education reported by acknowledged scholars in the educational field. Most notably, Gert Biesta (2012) has termed this as the rise of the language of learning. According to Biesta, this is an outcome of partially related developments, such as the postmodern critique of authoritarian forms of education, neo-liberal ways of thinking, the impact of the Internet, and especially, constructivism. Biesta sees that the language of learning has led to a hollow notion of the teacher as a servant, retrieving its justification from constructivism, which does not operate only as a learning theory or as an epistemology, but also as a pedagogy in which students construct their own insights and knowledge (also see BINGHAM, 2015). 
internal goods of teaching in philosophy for children: the role of the teacher and the nature of teaching in philosophy for children

PFC is grounded in a version of social constructivist epistemology and is also attached to postmodern critics; this raises a need to address the role of the teacher and the nature of teaching in PFC pedagogy. ${ }^{3}$ Bingham (2015) urges proponents of PFC to re-think some of its original commitments and take a leading role as a teaching movement. Surely this depends on what we mean by teaching in this unique practice that is located at the crossroads of education and philosophy. It is my primary task to give an account of the nature of teaching and the role of the teacher in the pedagogy of PFC. A point of departure is Alasdair Macintyre's (1984) conceptualization of internal goods, which will serve as a framework for considering PFC in terms of teaching. Macintyre's moral theory rests on the concept of social practice. According to Macintyre, for something to be a practice, it has to create internal goods, which capture a distinctive vision of what it is worthwhile to achieve. Interestingly, Macintyre himself put forth a view that teaching is not a practice by claiming that teaching is just an activity that introduces practices with "a set of skills and habits put to the service of a variety of practices" (MACINTYRE; DUNNE, 2002, p. 5). This view has inspired arguments and insights defending teaching as a practice, as well as arguments in favor of Macintyre's view. ${ }^{4}$ My primary mission is not to dwell on this debate, but to articulate some central internal goods in the pedagogy of PFC, which give shape to the nature of teaching in PFC and unfold a particular commitment in the role of the teacher. My study advocates a view that teaching in PFC entails more than simply inducting students into different practices with a purely technical skill set. I am after a more nuanced and complicated consideration of teaching.

My paper is organized in the following way. I will start by briefly introducing Macintyre's (1984) main idea of what constitutes a practice and the vital role of internal goods in it. Against this background, I flesh out the internal goods of teaching in PFC by studying the scholarship of PFC. This is done by

\footnotetext{
${ }^{3}$ Juuso (2007) has argued that there is a lack of pedagogical action in the theorization of PFC, drawing his conclusions from the continental tradition of educational theory, where educational influence is seen as a necessary condition for growth. Kennedy (2004a) explicates the epistemological commitments in PFC drawing from Piaget, Dewey, and systems theory.

${ }^{4}$ See, for example, special issues in the Journal of Philosophy of Education 2003 and 2010.
} 
showing that the nature of teaching shapes the internal goods located within the teacher. Other internal goods are located in the work and the performance of the teacher, through which it is possible to articulate the role of the teacher in PFC. Lastly, I consider the need of the teacher's self-education as a condition for excelling in the practice of PFC.

\section{defining a practice}

Alasdair Macintyre's famous work After Virtue, published 1981, has triggered significant discourse among educational scholars, especially regarding whether or not we should see teaching as practice. It is beyond the scope of this article to go into this debate, except to suggest that there is something worthy in terms of teaching, in this case teaching in PFC. In the book, he offers an account for what can be called "a practice":

. . . any coherent and complex form of socially established cooperative human activity through which goods internal to that form of activity are realized in the course of trying to achieve those standards of excellence which are appropriate to, and partially definitive of, that form of activity, with the result that human powers to achieve excellence, and human conceptions of the ends and goods involved, are systematically extended. (MACINTYRE, 1984, p. 187)

Macintyre's account of practice stays true to Aristotle's by stressing action guided by a telos, which is the good of an activity. ${ }^{5}$ A good could be most succinctly defined as that for the sake of which we act. A crucial difference to Aristotle is in the way it locates the telos. For Macintyre, ethical authority is grounded in practices, which offers the first domain in which goods receive their meaning. ${ }^{6}$ In other words, ethical understanding does not guide practices, but is formed in them. ${ }^{7}$ A good is something judged valuable to achieve or attend to in a practice, and the goods of a given practice are the purposes for action. A virtue is closely related to goods in the traditional Aristotelian way of thinking as a

\footnotetext{
${ }^{5}$ One interesting feature of MacIntyre's concept of practice is that it does not make the Aristotelian distinction between praxis, where the end is found from the activity itself, and poiesis, where the end is detachable from the activity. For example, music and architecture are both regarded as practices in MacIntyre's account (see MACINTYRE, 1984, p. 187).

${ }^{6}$ Life narratives and moral traditions are two other moral contexts where goods receive their meaning in Macintyre's moral theory, but this article builds mainly on the context of practice.

7 In Aristotle, biology or human essence plays a bigger role in locating the telos.
} 
internal goods of teaching in philosophy for children: the role of the teacher and the nature of teaching in philosophy for children

disposition to act for the good and also as one constituting element of the good itself (ARISTOTLE, 1959). ${ }^{8}$

Macintyre's distinction between internal and external goods offers the starting point for deepening our understanding of goods. ${ }^{9}$ Roughly put, external goods are achieved when something is done for money, fame, or prestige and can be acquired in multiple ways. Internal goods give meaning to a particular kind of practice and can be had only from the inside out. Macintyre (MACINTYRE, 1984, p. 188) gives an example of a boy who is learning the game of chess. As long as the boy plays chess just because he is receiving candy afterward and receiving even more if he wins, the goods are external. So the boy is motivated to win, but not by the game itself, which might provoke an interest in cheating in order to reach his goal. Macintyre explains that "there might come a time when the boy will find those goods specific to chess, in the achievement of a certain highly particular kind of analytical skill, strategic imagination and competitive intensity, a new set of reasons" (MACINTYRE, 1984, p. 188). Thus, his actions would not only be guided by external goods (winning) by any means necessary, but by internal goods (the practice). ${ }^{10}$

What becomes clear from this example is that internal goods are essential for the realization of any practice. Chris Higgins (2010c) expands the notion of internal goods by making a distinction between the telos and the literal aim of a given practice. Inside each practice, there is a shared vision of what is worthwhile to achieve, and each practice has its own way of envisioning a finally perfected work, which captures the shared telos of a given practice. According to Higgins (2010c), "this evaluative teleology is closely related to but not reducible to the

\footnotetext{
8 In recent times, Aristotle's thoughts have informed for example social and emotional learning, communitarian brands of citizenship education and positive psychology's virtue theory. There are also many philosophers who have introduced new ways to interpret, apply and mediate Aristotle's heritage (see, for example, KRISTJÁNSSON, 2014; CURREN, 2010).

${ }^{9}$ Although Hager (2011) argues that this distinction is actually not as clear cut as Macintyre seems to assume, according to Hager, external goods are not always morally dubious as Macintyre seems to suggest in his examples. Hager sees that some external goods in productive practices can be morally neutral.

${ }^{10}$ Macintyre's theory as a whole is much more complex, and my brief sketch does not give credit to its overall architecture.
} 
more literal aims that structure the practice" (HIGGINS, 2010c, p. 246). Higgins finds this distinction in Macintyre's own examples; one of them is about a fishing crew whose aim is to catch fish, but never simply to catch fish, but "to do so in a manner consonant with the excellences of the craft" (HIGGINS, 2010c, p. 246).

Another useful and important structural notion can be found from the typology of internal goods also originally interpreted by Higgins (2010c). First, we can locate internal goods 1) in the practitioner and 2) in the products. The goods located in the products are more specifically located in works and performances, and the goods in the practitioner can be located in what Higgins calls moral phenomenology, biographical genre, and the excellence of character. I will address these components as they fit with my primary mission, and they will become clearer as we move along.

Next, the task is to search for the internal goods for PFC based on this typology and to see what it means in terms of teaching. If we accept the Macintyrean characterizations of a practice, we also accept that practices are the moral sources for action. Every practice is framed by its telos, which is the good of that activity. To act virtuously is to identify the goods and act towards the goods realized in a given practice.

\section{the nature of teaching}

As mentioned, the pedagogy of PFC builds on a notion of a community of inquiry, or more specifically (to emphasize the philosophical nature of such inquiry), on a community of philosophical inquiry (CPI). ${ }^{11} \mathrm{CPI}$ works in the realm of concepts usually starting from a puzzlement or a problem and trying to find the best argument or truth of the matter that settles the case, albeit just until a new problem is found (see SPLITTER, 2014). The complexities originate in the fact that it is a shared experience, where the creation of dialogical relations multiply. While I address something to someone, it is also addressed to the whole group and interpreted individually by each member.

\footnotetext{
${ }^{11}$ My assumption is that a philosophical dimension exists (but can remain hidden) in all inquiries, and so I will refer only to the community of philosophical inquiry.
} 
internal goods of teaching in philosophy for children: the role of the teacher and the nature of teaching in philosophy for children

Ideally, the group works towards a mutually coordinated perspective while accepting its fallibility and the possible errors and partialities in its pursuit. Still, it is striving towards a certain epistemic telos that is bounded by the Socratic notion of "following the argument where it leads" (KENNEDY, 2010, chp. 3). On the other hand, this telos is something out of reach, something impossible to predict, because the multiplicity of ways to move forward is dependent on the participants in the communal dialogue (KENNEDY, 2010).

If we take the distinction between the literal and the actual telos demonstrated in the example of the fishing crew, it seems that the epistemic quest as a search for truth works more as a literal aim of CPI and the telos has to do with (to use Aristotelian language) the manner consistent with the excellences of CPI. The telos of CPI would then not only be a communicative, but also a disposition towards dialogical relation, a wakened desire to understand the other (see JUUSO; LAINE, 2005). For example, Sharp's (2007) articulation of CPI as an activity that "fosters an ability to put one's ego in perspective" illuminates this internalized ability that grows out of the dialogue towards "a slow realization of what it is to be human and live the human predicament" (SHARP, 2007, p. 5). Also, Kennedy (2014) sees that by moving beyond epistemological "egocentrism," a more radical form hinges "on a new experience of alterity within the self" (KENNEDY, 2014, p. 27). Still, one needs to proceed here with caution because the degree of decentering, in more existential terms, ego, resonates with the degree of problematizing and deepens the understanding in the substance of $\mathrm{CPI}$, which are concepts.

This distinctive aspect is related to the philosophical "meta" nature of CPI. It is a practice beyond practices in the way it tackles the questions imbedded in various practices including itself. So we could say that the practice under investigation works on a meta-practical level fostering a community where different voices, that is, different practices, can also be heard in a substantive dimension. CPI aims to tackle various issues in a spirit that Macintyre (1999, p. 66) also sees as crucial: "there is the question of whether it is good for that society that 
the goods of this or that particular practice should have this or that place in its common life" (also see HIGGINS, 2010c, p. 243). In other words, CPI aims to offer a wider perspective to the cultural habits that cloud our thinking. Dewey (1963) talks about a possibility for cultivated naïveté that can be acquired through reflective thinking or by means of philosophical thought (also see GREGORY; GRANGER, 2012).

It is the activity, the doing of philosophy, the way of embarking with contestable, common, central, and connected questions that shapes the nature of teaching in CPI (SPLITTER, 2014; also see SPLITTER; SHARP, 1995). The experiential landscape calls for a willingness to take the risk of preparing for the unexpected and throwing oneself into a state ignorance. This enables more authentic exploration of meanings, connections, and relationships between ideas stemming from the dialogue. The fresh and open attitude seems to be more natural for children, but for the teacher, it calls for a readiness to "be 'killed and eaten' by the group" as a traditional authority figure (KENNEDY, 2004b, p. 753; also see HAYNES; MURRIS, 2013). Gregory and Granger (2012) see that CPI may enable the teacher to "decenter from adultism" in finding their own sense of wonder reawakening.

Both of these characteristics (the process and a certain attitude required by the substance) indicate a particular commitment to a state of being that seems worth pursuing (also see HIGGINS, 2010c). This experiential landscape is something Higgins (2010b) refers to as the distinctive moral phenomenology that is realized as an experience. So, although the internal good, once realized, is located in the teacher, its source is in the nature of teaching. To be more specific, the intelligibility is derived from the ideal nature of teaching understood in the practice of PFC. If we accept this, it follows that a teacher who is entering the practice should start by experiencing CPI. This might happen by arranging inquiries with faculty members or partaking in inquiries with children facilitated by more experienced members of the practice. This way, the teacher can get a grip on the nature of teaching in PFC. Working through this process, the teacher might 
internal goods of teaching in philosophy for children: the role of the teacher and the nature of teaching in philosophy for children

start to notice that he/she needs to change something within him/herself, in the way he/she encounters the students, and in the way he/she encounters the world. This would be the first step in entering the practice. The challenge is that a distinctive moral phenomenology is hardly observable; instead, it is something that is experienced. Still, an important proviso is that this experience is not something deemed to be good because it is pleasurable, although at times it surely can be, in the Macintyrean sense, this experience is good for its own sake and also contributes to general wellbeing (see MACINTYRE, 1999, p. 64).

Let's look at an example. When the teacher patiently holds his/her urge to give an account related to the issue at hand, but merely feeds the dialogue with questions, he/she can occasionally feel discomfort or irritation at the course of the discussion. There may be students intentionally distorting the dialogue by playing with double meanings or having other sorts of agendas (see MICHAUD, 2014). On other occasions, even when the whole group is interested in working together, the teacher might feel a state of panic when the dialogue gets stuck or breaks down because of too much generality or some other reason, and a deadly silence descends on the classroom. Still, every morning when the classroom is filled with students, the teacher is dreaming of an astonishing experience of mutual exploration, and sooner or later his/her perseverance is rewarded. This is to say that he/she is not doing it merely for the pleasure, but because, for him/her, there is something valuable in the activity itself. The experience of the distinctive moral phenomenology, with all the risks and feelings, offers its practitioners a vision into how it is excellent to be. At the same time, by offering a way of being in a particular world, it offers an insight into a way of being in the world (also see HIGGINS, 2010b).

\section{the role of the teacher}

In the ethos of PFC, there is a commitment to creating a social, political, moral, and aesthetic environment, a space where these aspects are under conscious scrutiny (see GREGORY, 2012). It is the creation of the environment where a teacher's excellence is measured and also techne comes into play. By this I 
do not mean purely technical reason, which would outstrip the possibility to conceive CPI as a practice and render it to technological or scientific formulations, "but a techne (Greek: skill, art, craft) based on a series of philosophical judgments, and in which the descriptive and the normative are in a chiasmic relationship" (KENNEDY; KENNEDY, 2011, p. 269).

To start with, this skill like ability can be found in the readiness for the signs of fruitful dialogue and in the momentous judgements made to discard the prepared lesson plan when a promising slot appears. On the level of an ongoing dialogue, the teacher has to make discursive moves like, for example, explicating the positions, summarizing, asking for clarification or definition, giving or asking for examples, indicating contradictions, or pointing out possible contradictions by generating alternative views (see, for example, KENNEDY, 2004b, p. 754; FISHER, 2003, p. 130; GREGORY; 2007). Interestingly, a teacher's judgement about the epistemic progress is not concerned with how close the community has moved towards the truth or consensus, but with criteria that Clinton Golding (2013) describes as 1) reaching mutual understanding "by the degree to which we appreciate the views of the other participants, or the degree to which they are mutually intelligible," 2) through advancing a distributed inquiry in "the movement from a problem and through a collective process." 3) by reaching inquiry milestones that are the products of each stage in an inquiry, for example, a consensus about an uncovered assumption in a suggested resolution, and 4) last but not least, by "reaching epistemic consensus about the procedures of our inquiry" (GOLDING, 2013, p. 427-434; also see GOLDING, 2017).

These epistemic criteria guide the community's standards of epistemic progress in CPI, and from educational perspective, can be viewed as an induction to collective philosophical thinking. The criteria also shift the focus from the literal aim toward the actual telos. The literal aim of truth-seeking does not articulate the manner consonant with the excellences of the craft, and there is a possibility that questioning becomes the most vicious tool of manipulation as exemplified in the movie The Paper Chase from 1973, or by Bingham's (2008) study on the relational 
internal goods of teaching in philosophy for children: the role of the teacher and the nature of teaching in philosophy for children

nature of authority (chp. 5; also see MICHAUD, VÄLITALO, 2017). Although there is a kind of extra-moral element in the excellence of questioning, the nature of teaching already sets some requirements for the proper spirit of CPI. So, in order to think of questioning as something pedagogically significant, we need to think of it as something more than just a technique to put to use in the classroom. A good internal to PFC, which intertwines around the concept of questioning, works in both intra- and inter-subjective modes of being; it is questioning as a permanent (dis)order of collective and individual habit, or as Lipman (2003) sees it, "questioning, more narrowly a quest for truth, more broadly a quest for meaning" (LIPMAN, 2003, p. 95). Furthermore, when the internal good of questioning is practiced in an educational context, it sets great possibilities, but also special challenges for the teacher. As an educational telos, questioning needs to be articulated accordingly.

\section{educational telos}

As discussed earlier, there is a multiplicity of ways to move forward in a dialogue, but we can also distinguish a multiplicity of aims at work in the educational task of the teacher. The teacher is confronted with institutional aims fleshed out in the curriculum, but we (especially PFC teachers) have a somewhat contrasting aim to free our students from oppressing structures in society (also see BIESTA, 2012; VÄLITALO et al., 2016). This is a complexity that comes into the picture when envisioning CPI as a structuring element of our teaching as a whole, entailing all aspects of classroom life, ${ }^{12}$ and therefore, being forced to face its institutional role. Biesta (2010) differentiates three broad domains of aims or purposes in education that he labels as qualification, socialization, and subjectification. Qualification can be roughly described as the domain of knowledge and skills; socialization, as the educational encounter with cultures and traditions; and subjectification as emphasizing education's orientation

\footnotetext{
12 This is something that is not always clear. Some seem to advocate Philosophy for Children as a separate activity from otherwise restrained curricular activities, and some construe a more holistic framework that entails a larger pedagogical vision.
} 
towards children and students as subjects of action, not objects of influence (BIESTA, 2012; 2010). Biesta (2015, p. 5) describes the work of the teacher thus:

Three dimensional thinking and doing also begins to reveal the complexities of even the smallest decisions and moments of action and doing in the work of the teacher ... the specific complexity of teaching, viewed from the perspective of the three-fold character of educational purpose, is that of three-dimensional chess, where three complete chess games are played on chess board hanging above each other, and where the pieces not only interact horizontally on each of the chess boards, but also vertically - so that a move in the "game" of qualification not only impacts what happens and can happen there, but at the very same time "does" something in the "games" of socialisation and subjectification, and vice versa.

Here, Biesta is also taking the game of chess as an example. Recalling Macintyre's understanding of a practice, it offers the first domain of purpose for the practitioner. In terms of PFC, the crucial question is: What is the game for? One current discussion inside PFC concerns the rules of the ownership of questioning (see TURGEON, 2015) where we can see that some are advocating students' primacy in questioning and see PFC as a pedagogy grounded in emergent epistemology where fresh and unique ways are prioritized and subjectification is seen as the most fundamental educational aim (see MURRIS; VERBEEK, 2014; KENNEDY, 2010; KOHAN, 2015). On the other hand, there are some who stress the teacher's role in the process and who are more inclined to see the historical canon of doing philosophy central in educational efforts suggesting that socialization and qualification are set as primary goals for the pedagogy of PFC (MCCALL, 2009; WORLEY, 2011). ${ }^{13}$ If we accept that these domains shape the game the teacher is facing in her task, the role of the teacher is also shaped in balancing between these purposes.

Therefore, what I am suggesting here is that we can distinguish two components in the teacher's task. One is orchestrating a fruitful platform for growth grounded in epistemic criteria, and the other is another level of specifically educational judgements the teacher must make. Educational judgements in themselves can then be divided into three dimensions. On one hand, to use

\footnotetext{
${ }^{13}$ All of these theorists give some credit to both aims, but the ones referred to here are clear in their priorities. Interestingly, Lipman (2003) seems to emphasize subjectification in his theoretical writings, but, especially teacher manuals, also offer strong emphasis for thinking skills.
} 
internal goods of teaching in philosophy for children: the role of the teacher and the nature of teaching in philosophy for children

Biesta's (2010) terms, the teacher has to consider the knowledge and skills (qualifications) that are seen as relevant for a given practice (i.e., academic disciplines), the ways of building a nest of reasons through which it is possible to comprehend the practice as a whole and find it meaningful to pursue (see WHITE 2009, p. 425). In PFC literature, this domain is often referred to as "thinking skills" (LIPMAN, 2003) or the "tools of thinking" (CAM, 2006). The dimension of socialization is related to the previous one, and it calls for judgements based on critical reflective engagement toward the traditions and cultures of which the practices are a part. For example, Darren Chetty and Judith Suissa $(2017$, p.16) see that

the vigilance and humility required of white educators, then, means reminding ourselves of the moral and political context in which our educational efforts make sense, reflecting on our own racialized identities and those of the people in our classrooms.

Thirdly, the teacher should be occupied with the question of how her actions impact the student as a person. What possibilities could the engagement with CPI offer in terms of being and becoming a unique subject? (See BIESTA, 2010.)

PFC can offer an avenue to acknowledge and be occupied with these three dimensions of education in terms of searching for the right balance between the sometimes-conflicting purposes of education, because it offers rich opportunities for a teacher to participate in a dialogue with the past, present, and future, with the term "dialogue" understood in its broadest sense. Three significant dialogues exist in terms of the purpose of education that PFC practice opens for the teacher (see, also HIGGINS, 2010a). First, she can take part in the dialogues of philosophy, where she has access to the "voices" that have developed through time and is thus able to enjoy the conversation and yet deepen her understanding of it. Second, she can enter a dialogue of human development and participate in a conversation with educational thinkers, past and present (see also HIGGINS, 2010a, p. 442). This opens the doors to a wide range of ways to approach fundamental life questions, which are, in the end, closely linked to philosophy but focus on education. For example, this dialogue can give perspectives on the ways traditions are 
represented to children and young people in explicit and hidden ways. Third, she can enter a conversation with the different "voices"; a conversation that unfolds naturally when encountering children who "still know how to be serious in their play, and playful in their seriousness" (HIGGINS, 2010a, p. 441). Also, Kohan (2014) urges us to prepare for a different form of reason, a different theory of knowledge, and a different ethic. It is a conversation where the excellence lies in ways of responding to the courageous but fragile enquiries of children so they are not swallowed by the totality or sameness of the other (most often, the teacher). Being drawn into these conversations reveals one good internal for the PFC teacher, which is wide reading and deep thinking to understand our reality, our social existence, and ourselves.

This internal good unfolds as a distinct biographical genre, a distinct way of life informed by the practice. Macintyre talks about the good of a certain kind of life. Just as a painter can live her life in different ways writing her own unique life narrative, there is still a meaning to living a painterly life to a greater or lesser degree (MACINTYRE, 1984). The biographical genre is a narrative structure for linking the past, present, and future in a meaningful way within a practice (see HIGGINS, 2010c). Participation in dialogues in a broad sense gives an idea of the philosopher-teacher's life. Related to the telos of questioning, we can describe the life of a philosopher-teacher as the life of a questioner.

\section{entering the practice}

The internal goods of PFC constitute a practice where the philosophical teacher or the educational philosopher can flourish. Kohan (2015) sees the connection (in discussing the difference between a philosopher and a pedagogue with Jan Maschelein) as unintelligible to see "the teacher as an additional feature of the philosopher than it does to see philosophizing as an additional feature of a teacher" (KOHAN, 2015, p. 85).

Although the bond between philosophy (in the way described here) and teaching is very tight, there is still a distinguishable educational and philosophical contribution worth considering. When the philosophical question, "how to live," 
internal goods of teaching in philosophy for children: the role of the teacher and the nature of teaching in philosophy for children

becomes an educational question, "how to educate," the nature of the question changes as it becomes necessarily relational. The question comes to life when we become parents or decide to work in the field education. For the teacher, the relation to the good of the student symbolizes the good of the culture or the good of the species (not only to the ones with blood ties) adding a responsibility for the common good. The teacher's care for the student (independent of the subject) animates the helping of students (as individuals) in their never-ending search for a good life (see NODDINGS, 2003). The wakened relational care motivates the teacher to search for educational practices that share the concerns with which he/she is confronted. When becoming a member of a practice such as PFC, the care unfolds as a commitment to aspire towards the internal goods of the practice. For Macintyre (1984, p. 190), "to enter into a practice is to accept the authority of those standards and the inadequacy of my own performance as judged by them". While accepting the internal goods of PFC, the question of educational purpose makes the whole mission intelligible, and most of all, visible. Dewey (1916, p. 128) writes that

a truly general aim broadens the outlook; it stimulates one to take more consequences (connections) into account. This means a wider and more flexible observation of means. The more interacting forces, for example, the farmer takes into account, the more varied will be his immediate resources.... Then the more general ends we have, the better.

Biesta's multidimensional telos is an attempt to articulate the multilayered purpose of education. For the philosophical teacher, this is the broader framework for the teacher's excellence. In the end, the excellence lies in the everyday judgements of differing circumstances balanced with the multidimensional and sometimes conflicting purposes of education.

In developing his/her excellences, the PFC teacher serves a tangible practice and a platform for the teacher in the pursuit of the telos with a thicker articulation of internal goods worth striving for. The commitment to the practice of PFC also means that if we want to educate well, to make good judgements in our work as teachers, it is necessary to disclose our own self-cultivation, and for a philosophizing teacher, that means a commitment to continuing growth, which is 
the point where educational questions round to philosophical questions. Working with children is working with oneself because it continually calls for listening to the inner voice, the child's voice within us. The child within is our experiences, possibilities, and desires springing from the conditions we once lived, and still live within (also see KENNEDY, 2010). These avenues of self-study enable us to make good judgments in our work as teachers.

\section{conclusion}

I started with a problem: What is the nature of teaching and the role of the teacher in PFC? To answer this, I applied MacIntyre's concept of practice as a first context of internal goods in PFC. Based on this definition, I located part of the internal goods in the practitioner, which are characterized as a disposition towards dialogical relation and a certain willingness toward a state of ignorance shaped by the nature of CPI. Other internal goods were located in the work or performance of the teacher. Here I made a distinction between the actual telos of questioning as a philosophically and educationally meaningful activity and questioning as mere search of truth. This makes PFC a distinct practice not only as a part of philosophy, but as an educational practice.

I argue that the teacher appears when we are forced to turn a philosophical question into an educational one. In terms of PFC, this simple move turns the facilitator into a teacher. As simple as it is, it presents the crucial element of care for the growth of the student independent of the subject. The care is first and foremost about helping students in their quest for a good life and caring about the ways this quest gets enacted. In answering the question "how to educate?" the teacher is balancing a multidimensional purpose and is forced to take the role of a tragic protagonist in his/her daily judgements. He/she must choose what he/she sees as the most desirable end in a particular moment, and often, that comes at a cost in terms of some other end. Still, this challenge is the moving force of a philosophical teacher, and PFC pedagogy can serve as a practice in the encounter of the greatest good: the growth of the student. The way the philosophical-teacher can tackle this telos is by sustaining the continuous quest for the good beyond 
internal goods of teaching in philosophy for children: the role of the teacher and the nature of teaching in philosophy for children

practices, a quest MacIntyre (1984, p. 219) declares as the good life for man: "the good life for man is the life spent in seeking for the good life for man". The unexamined life is not worth living, nor teaching.

\section{references}

ARISTOTLE. 1959. The Nicomachean Ethics of Aristotle. Translated by David Ross. London: Oxford University Press.

BIESTA, Gert. 2015. The duty to resist: Redefining the basics for todays's schools. Research on Steiner Education 6, 1-11.

BIESTA, Gert. 2012. giving teaching back to education. Phenomenology \& Practice 6, no. 2:35-49.

BIESTA, Gert. 2011. Philosophy, Exposure, and Children: How to Resist the Instrumentalisation of Philosophy in Education. Journal of Philosophy of Education 45, no. 2:305-319.

BIESTA, Gert. 2010. Good education in an age of measurement. Boulder, CO: Paradigm Publ. BINGHAM, Charles. 2015. Philosophy for Children as a Teaching Movement in an Era of Too Much Learning. Childhood and Philosophy 11, no. 22:223-240.

BINGHAM, Charles. 2008. Authority is relational. Albany: State University of New York Press.

CAM, Philip. 2006. Twenty Thinking Tools. Camberwell, Vic: ACER Press.

CURREN, Randall. 2010. Aristotle's educational politics and the Aristotelian renaissance in philosophy of education. Oxford Review of Education 36, no. 5:543.

DEWEY, John. 1963. Experience and education. New York: Macmillan Company.

DEWEY, John. 1916. Democracy and Education. New York: Macmillan Company. FISHER, Robert. 2003. Teaching thinking. 2. ed. London: Continuum.

GOLDING, Clinton. 2017. Getting better ideas: a framework for understanding epistemic philosophical progress in Philosophy for Children. In The Routledge International Handbook of Philosophy for Children, edited by Maughn Gregory, Joanna Haynes and Karin Murris. New York: Routledge.

GOLDING, Clinton. 2013. We Made Progress: Collective Epistemic Progress in Dialogue without Consensus. Journal of Philosophy of Education 47, no. 3:423-440.

GREGORY, Maughn. 2012. A Philosophy of Education for teaching reasoning in PreCollege Classrooms. In Philosophy and Education. Newcastle upon Tyne: Cambridge Scholars Pub.

GREGORY, Maughn. 2007. A framework for facilitating classroom dialogue. Teaching Philosophy 30, no. 1:59.

GREGORY, Maughn. 2004. Practicing democracy: social intelligence and philosophical practice. International Journal of Applied Philosophy 18, no. 2:161-174.

GREGORY, Maughn; GRANGER, David. 2012. Introduction: John Dewey on Philosophy and Childhood. Education and Culture 28, no. 2:1-25.

HAGER, Paul. 2011. Refurbishing MacIntyre's Account of Practice. Journal of Philosophy of Education 45, no. 3:545-561.

HAYNES, Joanna; MURRIS, Karin. 2013. Child as Educator: Introduction to the Special Issue. Studies in Philosophy and Education 32, no. 3:217-227.

HAYNES, Joanna; MURRIS, Karin. 2011. The Provocation of an Epistemological Shift in Teacher Education through Philosophy with Children. Journal of Philosophy of Education 45, no. 2:285-303. 
HIGGINS, Christopher. 2010a. Teaching as Experience: Toward a Hermeneutics of Teaching and Teacher Education. Journal of Philosophy of Education 44, no. 2-3:435-478. HIGGINS, Christopher. 2010b. Working Conditions: The Practice of Teaching and the Institution of School. Journal of Philosophy of Education 44, no. 2-3:371-397.

HIGGINS, Christopher. 2010c. Worlds of Practice: MacIntyre's Challenge to Applied Ethics. Journal of Philosophy of Education 44, no. 2-3:237-273.

JUUSO, Hannu. 2007. Child, Philosophy and Education : discussing the intellectual sources of Philosophy for Children. Oulu: Oulu University Press.

JUUSO, Hannu; LAINE, Timo. 2005. Tact and Athmosphere in the Pedagogical Relationship. Analytic Teaching 25, no. 1:1-17.

KENNEDY, David. 2014. Neoteny, Dialogic Education and an Emergent Psychoculture: Notes on Theory and Practice. Journal of Philosophy of Education 48, no. 1:100-117.

KENNEDY, David. 2010. Philosophical dialogue with children : essays on theory and practice. Lewinston: Edwin Mellen Press.

KENNEDY, David. 2004a. Communal philosophical dialogue and the intersubject. International Journal of Applied Philosophy 18, no. 2:201-216.

KENNEDY, David. 2004b. The Role of a Facilitator in a Community of Philosophical Inquiry. Metaphilosophy 35, no. 5:744-765.

KENNEDY, Nadia; KENNEDY, David. 2011. Community of Philosophical Inquiry as a Discursive Structure, and its Role in School Curriculum Design. Journal of Philosophy of Education 45, no. 2:265-283.

KOHAN, Walter. 2015. Childhood, Education and Philosophy : New Ideas for an Old Relationship. New York: Routledge.

KOHAN, Walter. 2014. Philosophy and Childhood: critical perspectives and affirmative practices. New York: Palgrave Pivot.

KRISTJÁNSSON, Kristján. 2014. There is Something About Aristotle: The Pros and Cons of Aristotelianism in Contemporary Moral Education. Journal of Philosophy of Education 48, no. 1:48-68.

LIPMAN, Matthew. 2003. Thinking in education. 2nd ed. Cambridge: Cambridge University Press.

LIPMAN, Matthew; OSCANYAN, Frederick S.; SHARP, Ann M. 1980. Philosophy in the classroom.2. ed. ed. Philadelphia: Temple Univ. Press.

MACINTYRE, Alasdair. 1999. Dependent Rational Animals. Chigaco: Open Court.

MACINTYRE, Alasdair C. 1984. After virtue. 2. ed. Notre Dame, Ind: Univ. of Notre Dame Pr.

MACINTYRE, Alasdair; DUNNE, Joseph. 2002. Alasdair MacIntyre on Education:

Dialogue with Joseph Dunne. In: Journal of Philosophy of Education 36, no. 1:1-19.

MATTHEWS, Gareth B. 1984. Dialogues with children. Cambridge, Mass.: Harvard Univ. Pr.

MCCALL, Catherine. 2009. Transforming thinking.1. publ. ed. London: Routledge. MICHAUD, Olivier. 2014. A qualitative study on educational authority, shared authority and the practice of philosophy in a kindergarten classroom: A study of the mulitple dimensions and complexities of a democratic classroom. Ph.D. diss., ProQuest Dissertations Publishing. MICHAUD, Olivier; VÄLITALO, Riku. 2017. Authority, democracy and philosophy: the nature and role of authority in a community of philosophical inquiry. In The Routledge Handbook of Philosophy for Children. New York: Routledge.

MURRIS, Karin; VERBEEK, C. 2014. A foundation for foundation phase teacher education: making wise educational judgements. South African Journal of Childhood Education 4, no. 2:1-17. 
internal goods of teaching in philosophy for children: the role of the teacher and the nature of teaching in philosophy for children

NODDINGS, Nel. 2003. Is Teaching a Practice? Journal of Philosophy of Education 37, no. 2:241-251.

SHARP, Ann M. 2007. The Classroom Community of Inquiry as Ritual: How we can Cultivate Wisdom. Critical and Creative Thinking 15, no. 1:3-14.

SPLITTER, Laurance. 2014. Preparing Teachers to 'teach' Philosophy for Children. Journal of Philosophy in Schools 1, no. 1:89-106.

SPLITTER, Laurance J.; SHARP, Ann M. 1995. Teaching for better thinking.1. publ. ed. Melbourne, Victoria: ACER.

SUISSA, Judith, and Darren Chetty. 2017. 'No Go Areas' - Racism and Discomfort in the Community of Inquiry. In The Routledge International Handbook of Philosophy for Children, edited by Joanna Haynes, Maughn Gregory and Karen Murris. New York: Routledge. TURGEON, Wendy. 2015. The Art and Danger of the Question: Its Place Within Philosophy for Children and Its Philosophical History. Mind, Culture, and Activity 22, no. 4:284-298.

VÄLITALO, Riku; JUUSO, Hannu; SUTINEN, Ari. 2016. Philosophy for Children as an Educational Practice. Studies in Philosophy and Education 35, no. 1:79-92.

WHITE, John. 2009. Education and a meaningful life. Oxford Review of Education 35, no. 4:423-435.

WORLEY, Peter. 2011. The if machine. London [u.a.]: Continuum.

received in: 12.02 .2017

accepted in: 10.04.2017 